\title{
Principles of Formation of Flexible Manufacturing Systems
}

\author{
Mikuláš HAJDUK, Marek SUKOP, Ján SEMJON, Rudolf JÁNOŠ, Jozef VARGA, Marek VAGAŠ
}

\begin{abstract}
The article presents points necessary for the production re-prophilation into the flexible one through the generation of so called flexible manufacturing cells. Mentioned are the reasons and effects which are brought by the flexible production. In general, the key to the generation of the flexible production is the group technology based on the principle of the material flow analysis. The variants of the possible solutions based on the material flows confirm that the problem of the flexible manufacturing cells generation is not an easy one and unambiguous either. But considering only this one criterion is not sufficient for the practice because it does not consider for example the number of the pieces. Therefore the present article in the principle points at the application of the multiplied criteria about the part or machine, based on which more specifically stated is the cell profile, as number of machines, type of machines, intercellular transfers and so on.
\end{abstract}

Keywords: flexible cellular; flexible manufacturing cell; material flow; re-prophilation

\section{INTRODUCTION}

Cellular manufacturing became recently one of the most important studies of the production systems arrangement. It is understood as the production philosophy based on the fact that the parts are similar to each other in their shape and manufacturing processes. Resolution of their similarity is enabled by the parts grouping into the groups according to the machines, which they share in the course of their processing and in such way the economical effect of the serial production is achieved.

At the present time, there is room for the competition struggle for the companies with strong innovation ability. The advantage gained based on the excellent new products is growing if these products are produced in the shortest possible time.

Changes of the strategies bring about new approach to the production forming, particularly to the flexible manufacturing [17].

The flexible manufacturing has to achieve the effect mainly based on the changes. It means that the application of the principles that have been followed so far in the design of the machinery productions is actually becoming invalid and front rank is becoming a completely new view on the manufacturing forming and its organisation [3].

Evaluation of the significance of the flexible manufacturing must be seen first of all in the possibility of the variety of parts of small size batches manufacturing automation. It follows out from the fact that flexibility can be achieved not only on NC machines, robots - this can have even the classical production, based mainly on the structure of grouping. In the middle of seventies, Burbidge stressed the significance of the group technology for the successful forming of the flexible productions based on the analysis of the production flow PFA- Production Flow Analysis. Problem is formulated by the incidence matrix part - machine, in which the element $a_{i j}=1$ if part $\mathrm{Pi}$ requires machine $\mathrm{Si}$, in other cases is $a_{i j}=0$. In such formed matrix one may look for the suitable clusters for forming the production cells as the principal units of the flexible production [4].

There are no doubts today whether to build the flexible production. Even if there are rather numerous objections related to the effectiveness of the flexible manufacturing cells, their number still grows [1].

\section{FACTORS AND REASONS INVOKING THE RE- PROPHILATION}

The principal priority of the company is the sale of the products or services. However, there is severe competition on the market and it is very difficult to stay on so demanding market. Even more difficult is to enter such market. The market is characterized by the continuous cycle of the changes and uncertainty. The level of the uncertainty is still growing, which is objective fact and phenomenon existing in the recent modern market economy. The recent economical environment may be characterized by the fact that there is enormous growth in the vigorous competition, new products and new manufacturers emerge on the market rapidly, new suppliers and their conditions fluctuate, functionality of the products is extended, the time of products usage shortens and the terms of new product delivery on the market shorten as well, Fig. 1. It is caused not only by the demanding requirements of the clients, developments in science and continuous emerging of the new competitors, but also by the aspects of the economical and social development and problems arising in the society [9].

Recent turbulent changes bring about such phenomena that the opportunities at the market arise quickly and also quickly disappear. This means uncertainty and risk for the company. Not only the skill of the managers to recognize the new market voids as soon as possible becomes necessary, but for their fast occupation also the skill of the flexible and fast manufacturing adaptation. It is quite logical that company is forced to alter the recent manufacturing strategies and orientate them so that its competitiveness is strengthened and the economical effect is achieved [8].

Each company, if willing to face successfully the attack of the problems from outside as well as from inside, must adopt such strategies, Fig. 1, based on which it will be able to react rapidly on the opportunities, which uncertainty brings [11].

Under strategy understood should be the goal oriented generation of the future status and goals of the company, mainly from the point of selection of the 
products which will be produced, of the manufacturing technology and markets where they would be sold. The higher quality of the strategy, the more significant success would be. The company creates through its strategy the prerequisites for the long terms growth and at the same time executes such operations, which brings also the short term effect. However this idea may be also understood oppositely: based on its strategy the company carries out such operations which bring the short term effect and at the same time the prerequisites for the long term development are generated [7].

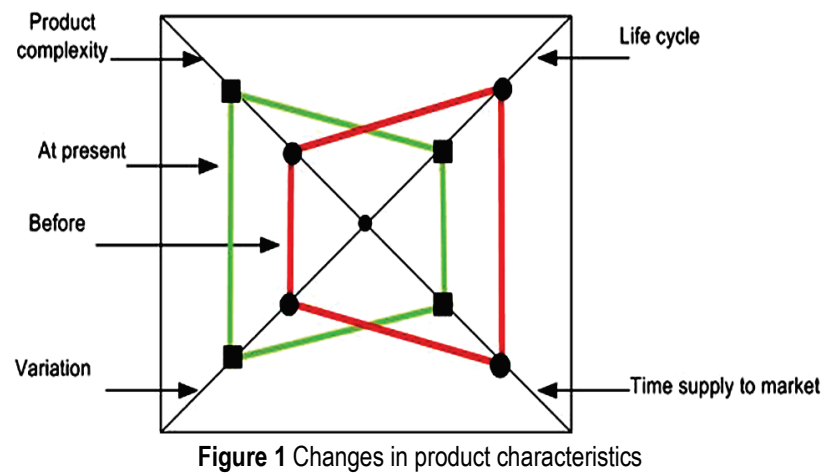

The selection of the strategies at the present time is determined by the conditions of the market. The strategies related to the production, should they be successful, must respect the fluctuation of the conditions on the market and re-prophile the production based on the new approaches. The new manufacturing technologies and philosophies, as the group technology, manufacturing cells, JIT, robotizing, CIM, have recently emerged. They call for new models and approaches if applied successfully. It is rational that the company directs its strategy in that direction, that through its exploitation strengthens its competitiveness and gains the economical effect [10].

Strategies to achieve the competitiveness and the flexible manufacturing call for:

- $\quad$ rapid adjustment to the new product

- rapid satisfaction of the client

- high quality

- adequate price.

Until present time applied manufacturing strategies were based on the production with the objective of their effectiveness. However at the present time, to be successful, they have to concentrate on the client while until present time, it has been the client who was to adjust; now it must be the manufacturer [12].

The flexible manufacture differs from the present manufacture in three principles:

- Size of the series, i.e. achieved are low production costs and short times for the machine and cell set up in case of the change; even in case of the small number batches

- Material flow, i.e. achieved is the execution of maximum number of operations in one spatial unit

- Variability of the activities, i.e. the ability to produce in time, to react to the changes between the order of the inputs and outputs of the material flows and information, and to determine the order of the operations as well, is achieved.
Reason for the recent structure of the manufacture reprophilation in the manufacturing cells is to achieve higher competitiveness. The manufacturing cells have shown to be one of the efficient manufacturing strategies in so rapidly changing economical environment [6].

\begin{tabular}{|r|l|l|l|l|l|l|l|l|l|}
\hline $\mathbf{P}$ & $\mathbf{M}$ & $\mathbf{2}$ & $\mathbf{3}$ & $\mathbf{4}$ & $\mathbf{5}$ & $\mathbf{6}$ & $\mathbf{7}$ & $\mathbf{8}$ & 9 \\
\hline 1 & & $\mathrm{x}$ & & & & & $\mathrm{x}$ & & \\
\hline $\mathbf{2}$ & & & $\mathrm{x}$ & & & & & & $\mathrm{x}$ \\
\hline $\mathbf{3}$ & & & $\mathrm{x}$ & & $\mathrm{x}$ & & & & $\mathrm{x}$ \\
\hline $\mathbf{4}$ & & $\mathrm{x}$ & & $\mathrm{x}$ & & & $\mathrm{x}$ & & \\
\hline 5 & $\mathrm{x}$ & & & & $\mathrm{x}$ & & & $\mathrm{x}$ & \\
\hline 6 & & $\mathrm{x}$ & & $\mathrm{x}$ & & & & & \\
\hline 7 & $\mathrm{x}$ & & & & & & & $\mathrm{x}$ & \\
\hline 8 & & & $\mathrm{x}$ & & & & & & $\mathrm{x}$ \\
\hline 9 & & & & & & $\mathrm{x}$ & & & \\
\hline 10 & & & & & $\mathrm{x}$ & $\mathrm{x}$ & & & \\
\hline
\end{tabular}

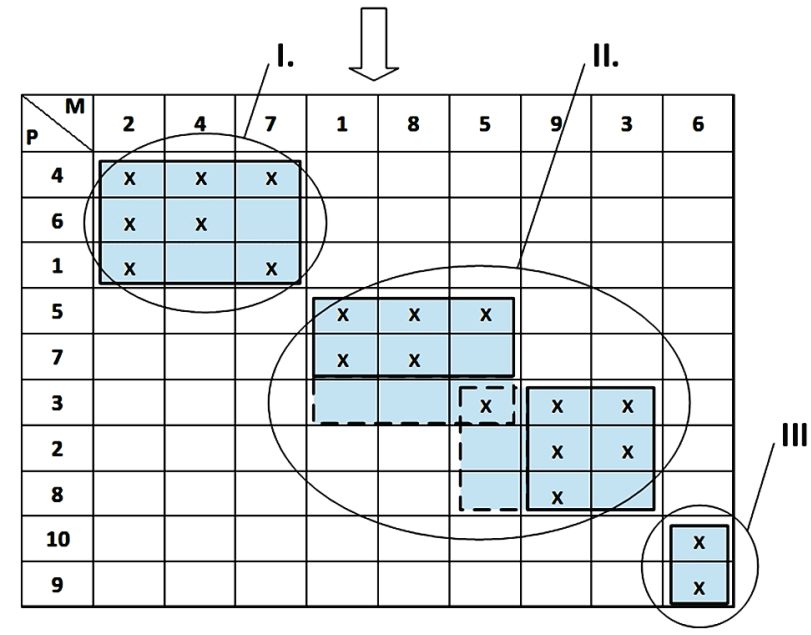

Figure 2 Three basic types of clusters

\section{CATEGORIES OF FLEXIBLE MANUFACTURING CELLS}

The procedure of looking for the group of the parts requiring the same machines is described by Burbidge, based on the production flow analysis - PFA (Production Flow Analysis). The problem is formulated by the binary matrix part - machine, in which then are searched the suitable clusters for the manufacturing cells generation, Fig. 2.

In the transformed matrix $\boldsymbol{M}^{\prime}$ may be seen three principal types of grouping:

I. Closed grouping, i.e. all parts are machined in the same cell

II. Grouping with intercellular transfers, i.e. matrix contains so called extraordinary parts, or machines, which may not be unambiguously allocated to certain cell

III. Grouping of parts requiring only one machine.

Based on these groupings it is possible for the definition of the manufacturing cells to use the classification of four types of the manufacturing grouping according to B. Maccarthy and J-Liu:

- $\quad$ SFM (Single Flexible Machine)

- MMFMS (Multi-Machine Flexible Manufacturing System) 
- $\quad$ FMC (Flexible Manufacturing Cell)

- MCFMS (Multi-Cell Flexible Manufacturing Systems).

Single Flexible Machine (SFM) is defined as the production unit formed by $\mathrm{NC}$ machine, completed by the manipulation facility to change the objects of the production.

Multi-Machine Flexible Manufacturing System (MMFMS) is understood as the grouping of several manufacturing machines without mutual dependence of their activity, for example AGV transport system. Machines are autonomous and their activity does not depend on the activity of other machines. These are first of all the machining centres, machines determined for special operations, as to produce the gearing, grinding operations and so on. Characteristic sign of their activity is the longer operation times [2].

Flexible Manufacturing Cell (FMC) is the manufacturing system, created by grouping several NC machines, determined for a certain group of parts with similar sequence of operations or for a certain type of operations. Characteristic sign of the cell is the mutual material and information interconnection among machines. Usually they apply for the interoperation manipulations a common manipulation facility.

Multi-Cell Flexible Manufacturing System (MCSMS) is formed by grouping of several manufacturing cells or cells and flexible manufacturing machines. Characteristic sign of this system is the existence of the intercellular transport system as the integrating element [15].
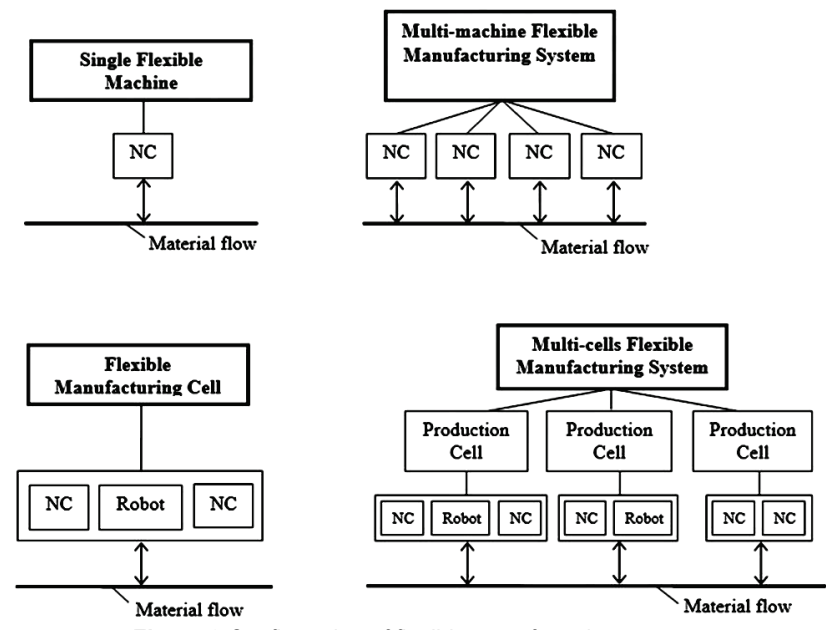

Figure 3 Configuration of flexible manufacturing systems

Based on the above classification it is obvious that two categories of the production systems: flexible manufacturing machine as the simplest type and flexible manufacturing cell, are the principal production units and the group of machines and multi-cellular grouping are their combination. Another characteristic sign of the flexible machine and cell is also the fact that they both have their own autonomous control. For the higher level of grouping, multi-machine and multi-cellular system, characteristic feature is that they have central type of control. The principal distinguishing sign of the cell from the multi-machine system is that the cell machines the specific group of parts requiring the same machines for their machining. The structures of in such way classified configurations of the manufacturing systems are illustrated in Fig. 3.

The presented classification scheme of the manufacturing groupings is based on the consistent set of definitions and determines the relations and limits among the individual systems and with the systems as well. The provided defined relations lead to the useful hierarchical models for the various types of the flexible manufactures and become useful in the solution of the control problems in particular, distribution of the manufacturing tasks, disposition localisation and material and information interconnections [14].

As mentioned before, many alternatives of the solutions and problems in the manufacturing cells prophilation arise, which in many cases may not be to solve unambiguously without considering several criteria [18].

As example for presentation of possible solutions of the manufacturing cells design three basic types of clusters will be described. The three kinds of groups for the machines will be examined in terms of:

- Maximizing material flow

- Maximize the capacitive loading of machines within the cell.

An example is the assembly of components which require just one machine, Fig. 4.

\begin{tabular}{|c|c|}
\hline & $\mathrm{M} 1$ \\
\hline $\mathrm{P} 1$ & $\mathrm{x}$ \\
\hline $\mathrm{P} 2$ & $\mathrm{x}$ \\
\hline $\mathrm{P} 3$ & $\mathrm{x}$ \\
\hline $\mathrm{P} 4$ & $\mathrm{x}$ \\
\hline
\end{tabular}

Figure 4 Sequence of operations for machine 1

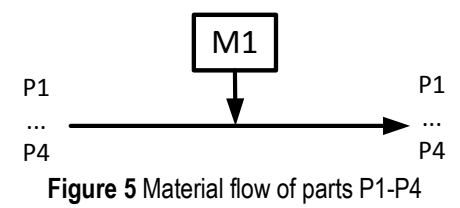

Possible cases: The sum of the capacitive loading of the machines by all the components does not exceed $100 \%$ e.g. It requires only one machine, Fig. 5 . The task is clear:

The sum of the capacitive loading of machines is greater than $100 \%$. For the manufacture of components two or more machines are required. In these cases, the group of sub-groups of components is created so that one specific component may be machined on one machine, Fig. 6. It is not always possible, however:

Another example is where a group of components requires more machines, but the grouping is closed. Much more variant structures of production cells are created for the group with multiple machines:

a, group of parts requires only a few machines (57), then you may consider a single cell, Fig. 7.

$b$, group of parts requires a larger number of machines, then they should be divided in two more cells, Fig. 8. 


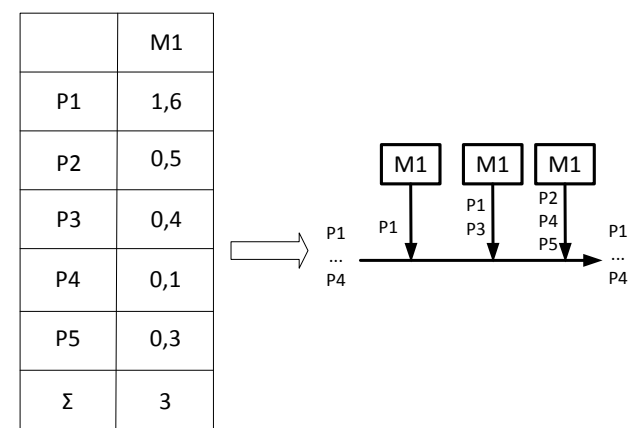

Figure 6 Sequence of operations and material flow for machines 1

\begin{tabular}{|c|c|c|c|c|}
\hline M & 1 & 2 & 3 & 4 \\
\hline 1 & $x$ & & $x$ & $x$ \\
\hline 2 & & $x$ & & $x$ \\
\hline 3 & $x$ & $x$ & & $x$ \\
\hline 4 & $x$ & & & $x$ \\
\hline 5 & & & $x$ & $x$ \\
\hline$\Sigma$ & 1 & 2 & 1 & 1 \\
\hline
\end{tabular}

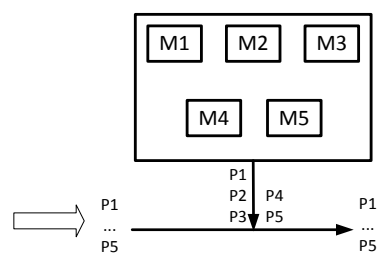

Figure 7 Sequence of operations and material flow for machines 1-4

\begin{tabular}{|c|c|c|c|c|}
\hline P M & 1 & 2 & 3 & 4 \\
\hline 1 & $x$ & $x$ & $x$ & $x$ \\
\hline 2 & & $x$ & $x$ & $x$ \\
\hline 3 & $x$ & $x$ & $x$ & \\
\hline 4 & $x$ & $x$ & & \\
\hline 5 & & $x$ & $x$ & \\
\hline$\Sigma$ & 2 & 3 & 2 & 1 \\
\hline
\end{tabular}

\begin{tabular}{|c|c|c|c|c|}
\hline M & 1 & 2 & 3 & 4 \\
\hline 1 & $x$ & $x$ & $x$ & $x$ \\
\hline 2 & & $x$ & $x$ & $x$ \\
\hline 4 & $x$ & $x$ & & \\
\hline$\Sigma$ & 1 & 2 & 1 & 1 \\
\hline
\end{tabular}
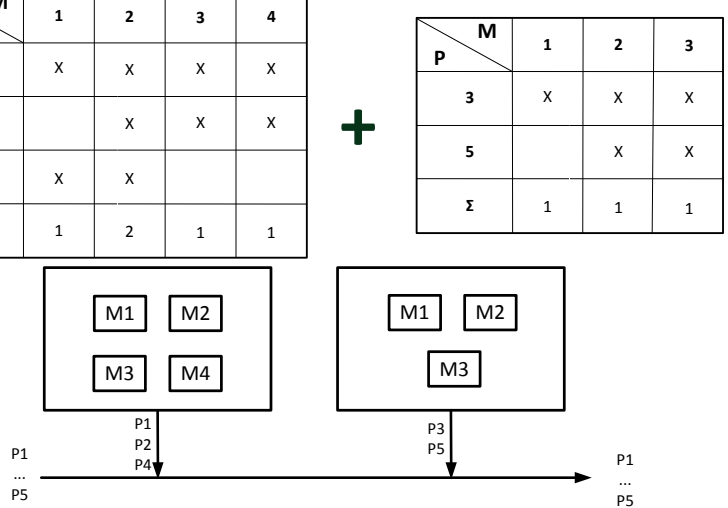

Figure 8 Sequence of operations and material flow for machines 1-4

A third example of a possible structure of production cells is the grouping with overlapping machines. They are the most common examples of clusters. There are many more variants of creating a possible structure of production cells, so we'll only list a few:

a, The required number of machines is small so we can create a single cell.

$b$, The required number of machines is greater, so the following approaches are possible:

- Problem machines are in both cells, Fig. 9.

- Problem machines form a separate cell, Fig. 10.

- Problem machines constitute a separate machine, Fig. 11.
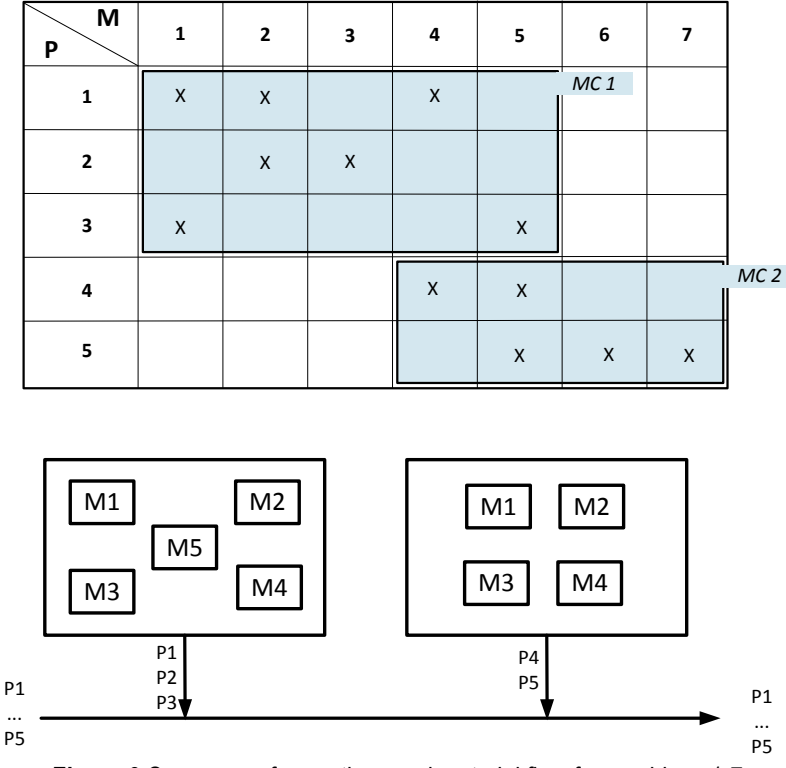

Figure 9 Sequence of operations and material flow for machines 1-7
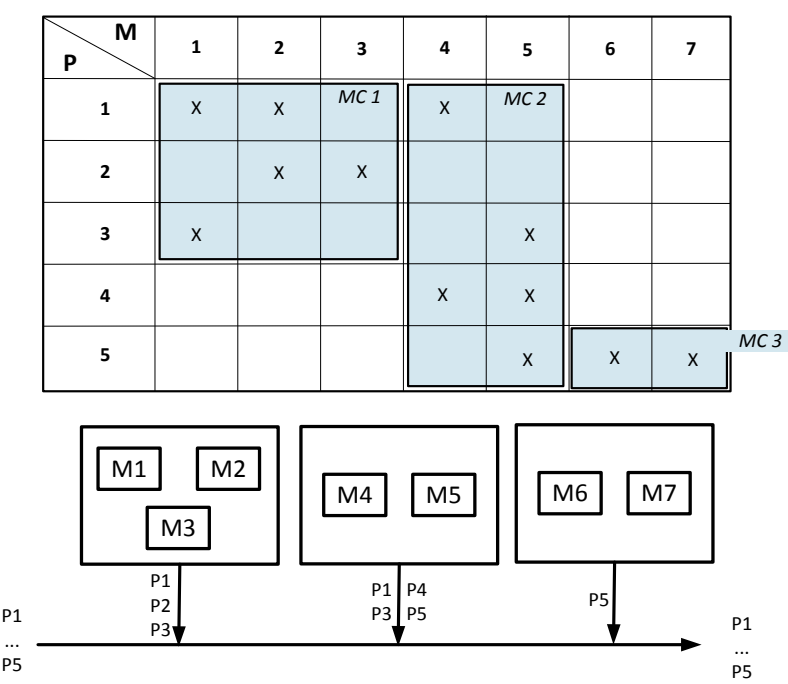

Figure 10 Sequence of operations and material flow for machines 1-7
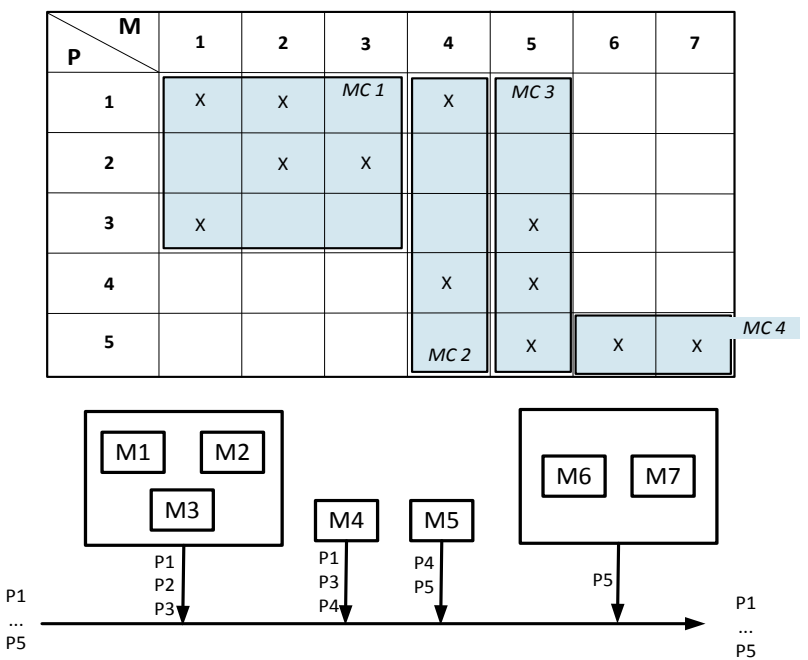

Figure 11 Sequence of operations and material flow for machines 1-7

Problematic machines are associated in one cell, while the movement of the problematic components is directly between the cells, Fig. 12 . 


\begin{tabular}{|c|c|c|c|c|c|c|c||}
\hline M & 1 & 2 & 3 & 4 & 5 & 6 & 7 \\
\hline 1 & $x$ & $x$ & $M C 1$ & $x$ & & & $M C 2$ \\
\hline 2 & & $x$ & $x$ & & & & \\
\hline 3 & $x$ & & & & $x$ & & \\
\hline 4 & & & & $x$ & $x$ & & \\
\hline 5 & & & & & $x$ & $x$ & $x$ \\
\hline
\end{tabular}

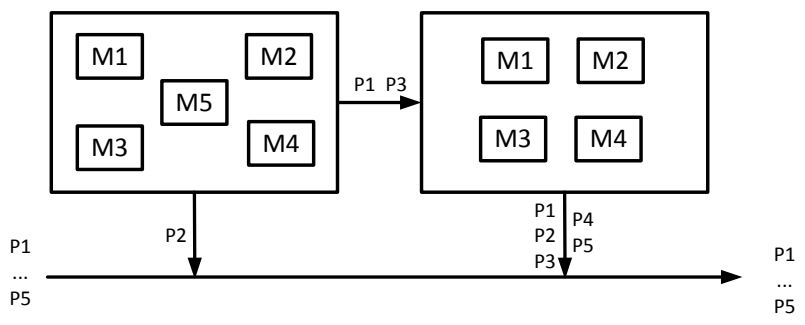

Figure 12 Sequence of operations and material flow for machines 1-7

\section{BENEFITS OF FLEXIBLE CELLULAR MANUFACTURING}

Cellular manufacturing offers substantial benefits to companies. These benefits include:

-Cellular manufacturing reduces material handling and transit times. By having the machinery to complete a certain process grouped together in a cell, the product spends more time on the machinery and less time in transit between machines. Because parts are moved within a cell rather than the entire factory, the travel time and distance are reduced, resulting in reducing the material handling cost, which constitutes between 20 and $50 \%$ of the total operating cost. By adopting cellular manufacturing, some companies reduced the cost of material handling by over $21 \%$

- Cellular manufacturing is based on the capability to produce families of similar products within each cell. Since similar parts are grouped, then it is possible that adjustments required to setup machinery would not be significant for each family product. The reported average reduction in setup times achieved by some companies ranges between 35 to $40 \%$.

- The decrease in setup time leads to an increased capacity of the machines as well as a decrease in work-inprogress inventories. Less Work in process (WIP) is easier to manage and allows the manufacturer to operate with shorter lead times [13].

- With decreased material handling and transit times, accompanied by the elimination of the queue times associated with batch processing, the time to produce one unit of a particular product becomes shortened, thus resulting in shorter delivery dates for the customer. Some companies achieved up to $24 \%$ reduction in manufacturing lead times [5].

- Cellular manufacturing systems, associated with onepiece flow, reduce work-in process inventories. With a continuous and balanced flow of product through the cell, no major build-up of material occurs between workstations, therefore eliminating the need of excess space to store in-process goods. This also allows workstations and machinery to be moved closer together, so there will be considerable floor space available for adding machines and for expansion.

- Cellular manufacturing system (CMS) also has an impact on manufacturing and design engineering areas. The effect for manufacturing is a reduction of the number and variety of parts, so the process planning for the remaining parts is easier and more consistent. CMS also paves the way for progression to computer integrated manufacturing. CMS assists in the economical justification or elimination of expensive NC machines in job shops [15].

- Communication is easy within each cell since every operator is close to the others. Ease of communication improves quality and coordination and the sense of common mission enhances teamwork in the cell [17].

- A cell on average employs a small number of workers that produce a complete part or product. Workers become multifunctional and are responsible for operating and maintaining numerous pieces of equipment and workstations. They are also able to cover other workstations within the cell when required to do so. In terms of worker productivity, the ability to deal with a product from start to finish creates a sense of responsibility and an increased feeling of teamwork. A common purpose and a sense of "ownership" is created among the production teams. Improving the production of the cell continuously and adjusting quality issues right away and not after an entire batch has been produced, greatly enhances the quality and efficiency of the production [16].

\section{CONCLUSION}

The flexible manufacturing systems have been generated with significant investments. The result was several "islands" of the automation of the small-series production, including the robotics, numerically controlled production technology, group technology, automation of the manipulation of the material. However the profit expected from those projects appeared only very slowly. Projects implemented in the practice did not meet the expectations as the costs, terms of their launching into the operation, meeting the terms of production, attaining the scheduled outputs. It is these deficiencies stemming from insufficient analysis in terms of groupings of machines and material flow between machines.

\section{ACKNOWLEDGEMENTS}

This contribution is the result of the project implementation: STIMULY č. Req-00169-0003 "Výskum a vývoj inteligentných mobilných robotických platforiem a polohovacích systémov $\mathrm{s}$ vysokou presnost'ou pre využitie vo výskume, vývoji a v priemysle" and project No. VEGA 1/0872/16 "Research of synthetic and biological inspired locomotion of mechatronic systems in rugged terrain".

\section{REFERENCES}

[1] Smrček, J., Palko, A., \& Tolnay, M. (2009). Robotika technické prostriedky pre automatizované pracoviská, Košice. 
[2] Arsovski, S., Arsovski, Z., \& Mirovic, Z. (2009). The integrating role of simulation in modern manufacturing planning and scheduling. Strojniski Vestnik/Journal of Mechanical Engineering, 55(1), 33-44.

[3] Swic, A. \& Mazurek, L. (2011). Modeling the reliability and efficiency of flexible synchronous production line. Eksploatacja $i$ Niezawodnosc - Maintenance and Reliability, 4(52), 41-48.

[4] Božek, P. (2013). Robot path optimization for spot welding applications in automotive industry. Tehnicki Vjesnik, 20(5), 913-917.

[5] Bubeník, P. \& Horák, F. (2014). Knowledge-based systems to support production planning. Tehnicki Vjesnik, 21(3), 505-509.

[6] Gola, A. \& Swic, A. (2011). Computer aided machine tool selection for focused flexibility manufacturing systems using economical criteria. Actual Problems of Economics, 10(124), 383-389

[7] Lehocká, D., Hlavatý, I., \& Hloch, S. (2016). Rationalization of material flow in production of semitrailer frame for automotive industry. Tehnicki Vjesnik, 23(4), 1215-1220.

[8] Srinivasan, M. \& Moon, Y. (1997). A framework for a goal-driven approach to group technology. Int. I. Production Research, 35.

[9] Sudhakara Pandian, R. \& Mahapra, S. S. (2009). Manufacturing cell formation with production data using neural networks. Computers \& Industrial Engineering, 56(4), 1340-1347. https://doi.org/10.1016/j.cie.2008.08.003

[10] Tolnay, M. et al. (2008). Methodical frame of reconfigurable manufacturing systems design. Acta Mechanica Slovaca.

[11] Wu, C. \& Barnes, D. (2016). Partner selection for reverse logistics centres in green supply chains: a fuzzy artificial immune optimisation approach. Production Planning and Control, 27(16), 1356-1372. https://doi.org/10.1080/09537287.2016.1221159

[12] Wagner, S. M. \& Walton, R. O. (2016). Additive manufacturing's impact and future in the aviation industry. Production Planning and Control, 27(13), 1124-1130. https://doi.org/10.1080/09537287.2016.1199824

[13] Gamboa, J. (2008). Intelligent Manufacturing Systems: a methodology for technological migration. Proceeding of the World Congress on Engineering.

[14] Hajduk, M. \& Šiovič, P. (1996). Profilation of Multicells Manufacturing Systems. CIM 96 / Zakopane.

[15] Hajduk, M., Klobušická, M., \& Šovič, P. (jún 2000). Nový pohl'ad na princípy skupinovej technológie pri profilácii pružných výrobných buniek. In. Medzinárodná konferencia Nové smery vo výrobných technológiách, Prešov.

[16] Tisley, R. \& Lewis, F. A. (1977). Flexible cell production systems a realistic approach. Annals of CIRP, 25(1), 265267

[17] Tolnay, M. et al. (2005). Structurated database of the manipulation transportion facilities for virtual enterprise. $18^{\text {th }}$ International conference on production research.

[18] Xambre, A. R. \& Vilarinho, P. M. (2007). Virtual manufacturing cell formation problem (VMCFP) in a distributed layout. Deparamento de Economia, B`Gestäo e Engenhania Industrial-Universidade de Aveiro.

\section{Contact information}

Mikuláš HAJDUK, Prof. Eng. PhD

Technical University of Kosice,

Faculty of Mechanical Engineering, Department of Robotics

Park Komenského 8, 04200 Košice, Slovakia

mikulas.hajduk@tuke.sk

Marek SUKOP, Assoc. Prof, PhD

Technical University of Kosice,

Faculty of Mechanical Engineering, Department of Robotics

Park Komenského 8, 04200 Košice, Slovakia

marek.sukop@tuke.sk

Ján SEMJON, Assoc. Prof., PhD

Technical University of Kosice,

Faculty of Mechanical Engineering, Department of Robotics Park Komenského 8, 04200 Košice, Slovakia

jan.semjon@tuke.sk

Rudolf JÁNOŠ, Eng. PhD

Technical University of Kosice,

Faculty of Mechanical Engineering, Department of Robotics Park Komenského 8, 04200 Košice, Slovakia

rudolf.janos@tuke.sk

Jozef VARGA, Eng. PhD

Technical University of Kosice,

Faculty of Mechanical Engineering, Department of Robotics Park Komenského 8, 04200 Košice, Slovakia jozef.varga.2@tuke.sk

Marek VAGAŠ, Eng. PhD

Technical University of Kosice,

Faculty of Mechanical Engineering, Department of Robotics Park Komenského 8, 04200 Košice, Slovakia

marek.vagas@tuke.sk 